\title{
Arranjos Paradigmáticos como Campo de Extração para um Jogo de Enquadramentos Híbrido ${ }^{1}$
}

\section{Rejane Kasting Arruda ${ }^{2}$}

\section{Resumo:}

Parte-se do traço histórico de movimentos antirrealistas no século $\mathrm{XX}, \mathrm{o}$ acento em suas diferenças e um denominador comum: a oposição a "uma visualidade fechada onde impera relações subjetivas a serem representadas". O caráter antirrealista se torna uma espécie de norte para a produção teatral contemporânea. No entanto, trava-se um debate ao postular o arranjo realista como propulsor de estranhamento, lançando mão proposições de Roubine e conceitos extraídos de Lacan e Dunker. O realismo aparece como uma poética fundamentada na descrença do olhar ou no efeito de alucinação. Pretendese alargar as perspectivas da aceitação do realismo como um dos possíveis campos de extração de materiais a serem misturados para a fabricação de novos arranjos contemporâneos.

Plavras-chave: teatro contemporâneo, pósdramático, realismo, poética cênica.

\begin{abstract}
:
Starts from a historic trace of anti-realistic movement of the twentieth century, the accent on their differences and a common denominator: the opposition to "a closed visuality whereitreignssubjectiverelationships to be represented". the anti-realistic character becomesakind of guidancetothecontemporary theatrical production. However, locking a debate by postulating realistic arrangement as propellant of estrangement, resorting Roubine's propositions and concepts from Lacan and Dunker. The realism appears as a poetic grounded in the disbelief of the look or the effect of hallucination. It is intended to enlarge the perspective of acceptance of realism as one of the possible fields of extraction materials to be mixed for fabrication of new contemporary arrangements.
\end{abstract}

Key-words: contemporary theater, post-dramatic, realism, poetic scenic.

1 Este artigo foi desenvolvido com recurso da FAPESP.

2 Doutora em Artes Cênicas pela Universidade de São Paulo; professora e coordenadora do curso de Artes Cênicas da Universidade Vila Velha (ES). Email: rejane.arruda@uol.com.b 
Tudo entreguei ao assombro.

Mesmo o mais familiar.

(Bertolt Brecht)

Já na primeira metade do século XX o paradigma da poética cênica como autônoma se estabeleceu, de forma múltipla, com projetos diversos. Vemos Meyerhold recuperar a visualidade do teatro de feira, dedicar-se ao grotesco e à abstração dos gestos; Brecht procurar o gesto estilizado, cuja primazia da forma implica a evocação da crítica (já que o ator inscreve a visualidade do seu pensamento e não "se esconde atrás" do enquadramento da ficção); Piscator intensificar as projeções, de maneira a sobrepô-las umas por cima das outras; a Bauhaus investir no ator como linha, grafismo; Craig teorizar o ator-marionete, projeto retomado em novos termos por Kantor, em um teatro onde a marionete é o modelo que o ator deve regar de vida; Grotowski se opôr à visualidade do gesto cotidiano e postular a ação física como um "ato total" (junto à visualidade do sacrifício e transe); Artaud dedicar-se às pesquisas com a sonoridade e o ritual para constituir o teatro como peste (termo que advém de Santo Agostinho, cuja "crueldade" é capturar o espectador, contagiá-lo de modo que perceba apenas quando é tarde demais) ${ }^{1}$ - há visualidade da relação com o espectador: "somos capazes de fazê-lo gritar" (ARTAUD, 2008, p. 31). E o Living Theater dedicar-se a rituais coletivos para constituir um teatro ativista, de cunho libertador no mundo escravizado pela indústria armamentista e uma série de ditaduras; vemos Bob Wilson imperar com o "Teatro de Imagens", sem a palavra do texto dramático ou quando sim, sobreposta pela força da plasticidade das imagens; vemos Barba constituir uma teoria do ator que lança mão da estilização nos teatros orientais como a principal referência; e as fronteiras entre ator e bailarino serem borradas com a Thanz-theater de Pina Bausch; o dado biográfico utilizado como material de trabalho moldado em montagem e constituído como poética; a proliferação do vídeo e materiais plásticos; a poética dos objetos e do som; a retomada da cultura popular como material cênico e a visualidade do oriente em trabalhos como os de Ariane Mnouchkine e Peter Brook.

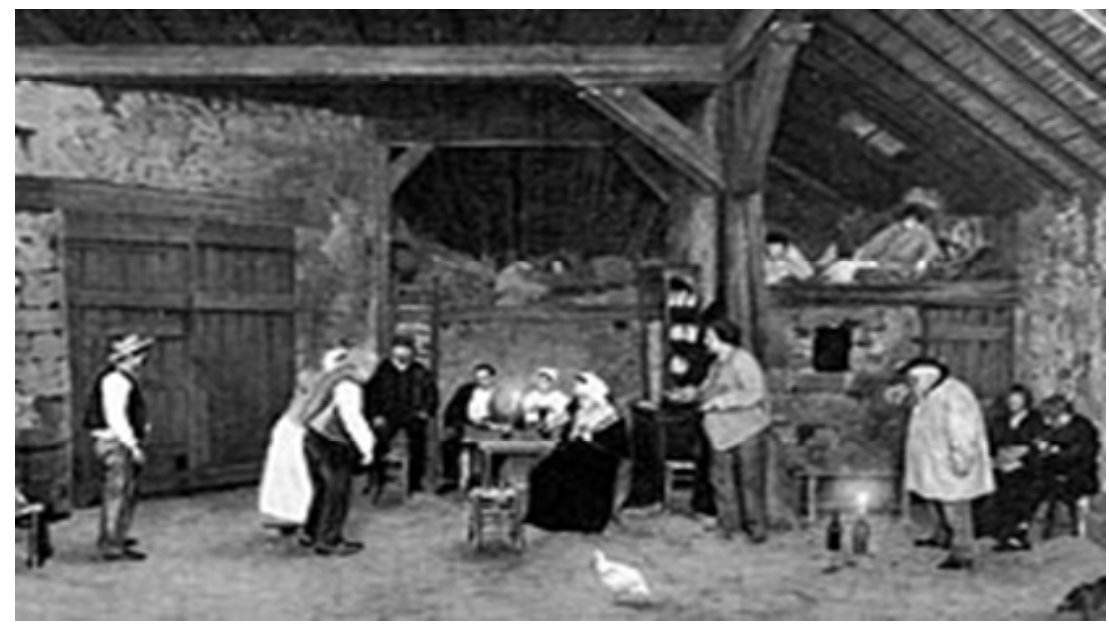

Figura 1: Téâtre Libre, fundado em 1887. Montagem de "A Terra" de Zola, por Antoine em 1902.

1 "O teatro tem efeito retardado; você já está mudado e não tinha percebido. É tarde demais para recuar" (WILLEMART, 1996, p. 206). 
De maneira que, sucessivos projetos antirrealistas marcaram, cada qual a seu modo, a consolidação de uma poética cênica autônoma em relação à literatura dramática ou à mimese da realidade proposta pelo projeto naturalista de Antoine. Até chegarmos ao que Lehmann designou como pós-dramático percebe-se uma recusa da visualidade de um universo diegético (ficcional) fechado. Este mundo, onde indivíduos encontram-se implicados em relações intersubjetivas (evocadas pelo texto) a serem representadas é posto em cheque. Em relação aos textos considerados pós-dramáticos, o conflito e a progressão oferecida pelo dramático é uma espécie de referência a ser quebrada, seja pelos elementos épicos ou por materiais que, entre outros, Jean-Pierre Sarrazac e JeanPierre Ryngaert se dedicam a consolidar. São figuras como: coralidades e partilhas de vozes, onde não se sabe mais quem está falando; a paródia, a citação e diversas misturas, que Sarrazac designa "monstros": "Não se trata de, em nome de qualquer modelo mecanicista, desumanizar o drama, mas sim de produzir obras contra naturam e preferir à imitação rígida da bela natureza a livre variedade dos monstros" (SARRAZAC, 2002, p. 56 apud BRAGA, 2007, p. 02) - uma miscelânea de tendências reelaboradas de modo singular por cada autor, de maneira que a contemporaneidade se configura como uma escrita múltipla.

A oposição que Lehmann faz ao dramático é explícita - e está articulada a uma tradição crítica alemã que passou por Walter Benjamin defendendo a narrativa e Peter Szondi operacionalizando um estudo da dramaturgia a partir da oposição entre épico e dramático. A posição de Sarrazac é diferente da posição de Szondi que, com a oposição do épico ao dramático, demonstra a falência do segundo; e de Lehmann, que defende a escritura cênica sem o texto que a anteceda. Sarrazac defende um texto híbrido - assim como Pavis postula uma cena híbrida, entre a performance e a encenação (com o que nomeou performise). Apesar da falta de interesse de Lehmann em problematizar este procedimento, o texto dramático tem estado presente no pós-dramático, como campo de extração de materiais, servindo ao encenador quando misturado ou posto em choque (seja com outros textos ou materiais plásticos). Tal como Krzysztof Warlikowski quando mistura fragmentos de "Otelo", "O Mercador de Veneza" e "Rei Lear"; ou Vitez quando "amarra" versos de Yannis Ritsos com pedaços de "Electra" (Sófocles); ou, ainda, Romeu Castellucci quando, ao montar "Julio César", coloca um ator obeso como Cícero (e a visualidade estranhada dos corpos entra em relação com a visualidade evocada no texto, gerando uma teatralidade específica daquele espetáculo).

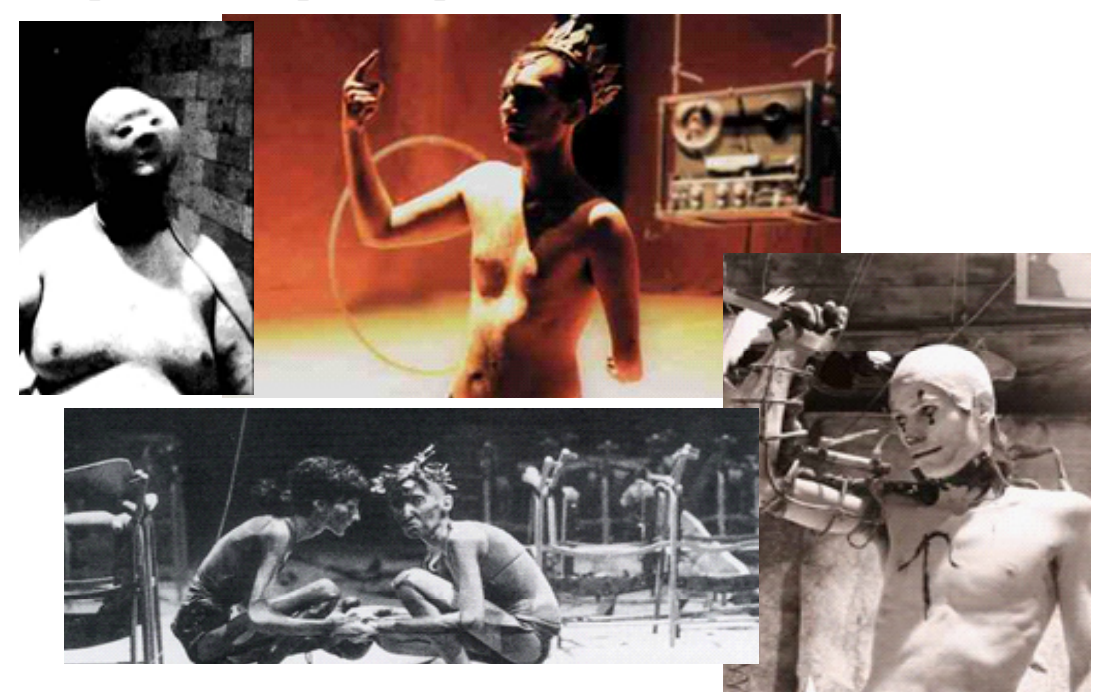

Figura 2: Imagens de Espetáculos de Romeo Castellucci 
No bojo da crítica ao teatro dramático está a ideia de que o ator "representa" - enquanto, no performativo, ele "age"; atua (em nome próprio e no momento). Algo semelhante ao que, no teatro naturalista (ou cujo projeto de atuação é naturalista) se demanda por: "o ator não representa, ele vive" (enquanto está enquadrado na imagem evocada de uma ficção). Segundo Roubine, o que Antoine buscava na "fatia de vida", acaba por causar o estranhamento de uma alucinação. A ficção "como se" fosse real, segundo Roubine "oferece ao espectador uma nova vertigem":

O exemplo paradigmático dessa vontade de deslocar as fronteiras que separa a realidade do campo da representação, de torná-los no fundo difusas, será Os açogueiros, de Fernand Icres (1888). Menciona-se bastante essa realização de Antoine, não sem alguma condescendência a respeito da pretensa "ingenuidade" do diretor. Imaginem. Ele havia decidido suprimir os acessórios tradicionais de cartolina mole e substituí-los por verdadeiras carcaças de carneiro, por "verdadeiros" pedaços de carne expostos no balcão do açougue que é o ambiente da peça! Mas Antoine era certamente menos "ingênuo" do que se dizia. Sabia que a confusão do fictício e do real e que o mimetismo integral no teatro definem uma utopia. Que o próprio da utopia é nunca se realizar. O problema é que, ao misturar as fronteiras, ao injetar, na imagem cênica, o real em estado bruto, ele expandia o campo referenciado da teatralidade e oferecia ao espectador algo como uma nova vertigem, a perturbação excitante da incerteza... $O$ século $X X$, através das buscas mais antagônicas, e frequentemente as mais afastadas do naturalismo, não será capaz de se lembrar que o real também pode se tornar teatro. E que tem uma "presença", como se diz, de extraordinária intensidade! O interesse da direção naturalista é que no fundo ela não designou claramente seu objetivo: acreditando que estava simplesmente desenvolvendo a arte do mimetismo, melhorando as técnicas da representação. O teatro não é mais apenas o lugar de uma ilusão mais ou menos "perfeita". Torna-se um espaço de alucinação. O espectador acredita que está deixando o real na porta do teatro. O real o alcança no cerne do espetáculo e o lança na deliciosa confusão de uma percepção sem referências estáveis (ROUBINE, 2003, p. 115)

"O século XX, através das buscas mais antagônicas, e frequentemente as mais afastadas do naturalismo" (ROUBINE, 2003, p. 115): deparamo-nos, o tempo todo, com os testemunhos das oposições; estas, que me ajudam a escolher materiais e montar arranjos de maneira a dialogar com uma cultura da cena e os seus principais impasses. Assim, uma plasticidade corporal do dia-a-dia ou "da realidade" pode se situar como uma das modalidades possíveis de enquadramento (em jogo), pois é tecida de imagem. Tal como a visualidade da progressão e desenlace dramáticos, da crítica ou da distância temporal (presente no teatro épico). Assim como o quadro de cinema ou da pintura; tal como um espelho (que reflete a imagem), a "realidade" é uma visualidade a partir da qual se pode extrair um fragmento. Não se configura como inteiriça, mas implica limites. Para que alguns dos seus elementos possam ser postos em cena, ela pode ser quebrada, assim como a diegese (que situa também limites). São visualidades, muitas vezes ofuscadas pela mise-en-scene - e é a partir deste fato que se estabelece uma tensão (que percebemos na prática teatral) entre a plasticidade da fábula e da cena; entre o texto (que evoca visualidades) e a encenação (que implica a sua própria visualidade e também evoca outras, diferentes daquelas evocadas pelo texto).

É possível utilizar materiais implicados nos arranjos da atuação naturalista. A divisão de foco entre uma atividade cotidiana e a relação com o outro é um exemplo; ou entre a fala interna e a externa; entre a diluição do gesto e a plasticidade do pensamento. Um jogo de enquadramento pode contar com a inscrição em um espaço-tempo ficcional enquanto o ator é situado, ali, como vivente. A ilusão da vida individual se inscreve; ela aparece: é vista. Nos projetos antirrealistas, ao contrário, 
a inscrição do corpo conta com diferentes modalidades de exacerbação de uma plasticidade cênica: uma poética da abstração da imagem ou da forma corporal; o jogo de evocação da crítica, da paródia; a visualidade da rua, da festa, da feira, do pop; da deformação, do ritual, do sacrifício; a visualidade da morte (como postula Kantor) ou do boneco, aproximando a cena teatral da pintura e dança moderna (ou as desproporções inscritas com as projeções de vídeos).

Quando pensamos no teatro pós-dramático como o lugar ao qual chegamos (pensando neste campo onde se inserem encenadores como Jan Fabre, Frank Castorf, Christoph Schilngensief, Rene Pollesch, Robert Lepage, Roger Vontobel, Romeu Castellucci, John Romão, Anatolli Vassiliev, Robert Wilson, Pina Bausch, Peter Brook, Ariane Mouchkine, Richard Foreman, Peter Stein e tantos outros), podemos dizer que, ao utilizar a cotidianidade (do corpo) que foi valorizada na poética realista, se rompe com um contexto ficcional (mostrando bastidores). Ou que se redimenciona o corpo, ampliando a imagem com projeções; trazendo à cena outra poética, como acontece em Katie Mitchell. A encenadora britânica criou um estilo particular de encenar, misturando vídeos e cena:

Uma mistura de cena viva e vídeos simultaneamente projetados daquela própria ação. Ter a câmera no palco para que você possa ver como as imagens são construídas (...). Em “Trem Noturno" são gabinetes no palco, existem câmeras em todo lugar, você pode ver alguém colocando o projetor. E lá na tela é bem realista. Isso é o que eu chamaria o lado brechtiano do pós-dramático no teatro. Como Brecht quis expor a mecânica da construção. ${ }^{2}$

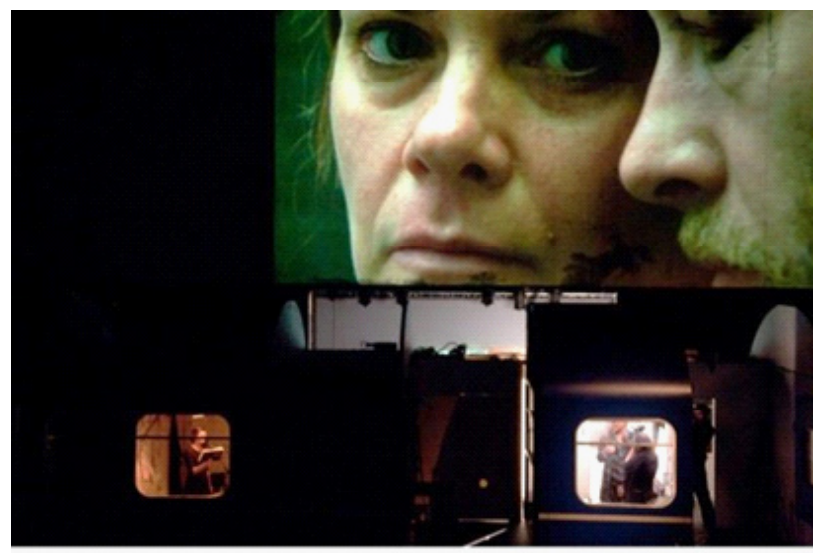

Figura 3: Night Train (Katie Mitchell, 2013).

Quanto à "atuação realista" no pós-dramático, não se produz a ilusão de que o ator é o personagem e de que a ficção está acontecendo. A não ser que o espectador faça parte da dramatização. Como no espetáculo "66 Minutes in Damascus”, apresentado na "Bienal Internacional de Teatro", no TUSP em $2013^{3}$. Situados no lugar de turistas a passeio no Líbano, espectadores são vendados e colocados em um carro que circula por São Paulo simulando um sequestro. De posse dos terroristas, o público é questionado sobre uma suposta reportagem enviada ao ocidente sem permissão. Passa por cubículos onde estão presos políticos, torturados em troca de informação. O espectador vive, em vertigem, "na pele", as desventuras de um sequestro; e debate, com os "sequestradores" a situação política do seu país.

Sucessivas pesquisas propõem uma quebra da "quarta parede" ou "espaço da representação",

2 Fala de Marvin Carlson no Colóquio Internacional "Pensar a Cena Contemporânea" em Florianópolis, UDESC, junho de 2013 (não publicado).

3 Dirigido por Lucien Bourjeily especialmente para o LIFT Festival 2012, em Londres. 
em troca de outros eixos onde o espectador se encontra tematizado. Teatro múltiplo, que não é o caso de detalhar aqui. Mas é importante que as oposições sejam testemunhadas, pois se situam como paradigmáticas para a escolha dos materiais na prática contemporânea com o texto dramático. $\mathrm{O}$ campo do Pós-dramático é um estimulo para a extração de materiais para um novo ateliê cênico. Mas também o arranjo da composição naturalista - que conta com uma divisão de foco entre interno e externo; cotidiano e relação; querer e agir; entre visualidade do pensamento e ação física.

Não apenas as múltiplas encenações pós-dramáticas podem nos servir como campos de extração (através de citações ou diluições, quando o material é transformado ou posto em relação), mas a sua teoria. Quando Robert Wilson se dispõe a defender o procedimento de colocar um sapo gigante em cena sem que este se articule ou evoque qualquer tipo de visualidade fabular, abre a perspectiva da experimentação. Quando o teatro pós-dramático traz materiais como areia, água, palha, argila, tinta, sangue (como vemos em Pina Bausch) sem que impliquem qualquer efeito de significação explicito na encenação, abre perspectivas da visualidade que se inscreve para além da inscrição na visualidade do drama. A presença dos materiais "nos causa" (nos engaja) sem que esteja inscrita na ficção onde a sua presença seria justificada.

\section{A cena que aponta para um lugar de não inscrição}

O sublime relaciona o respeito à Lei ao irrepresentável que ela barra.

(Maria Rita Kehl)

Lacan criou aforismos famosos como "o inconsciente é estruturado como uma linguagem" (LACAN, 1998, p. 144), sendo que, na linguagem, não se trata de relações unívocas entre significantes e significados, mas de deslizamentos (metonímias) e empilhamentos (metáforas), de maneira que um efeito de significação sempre se remete a outro significante.

A primeira rede, do significante, é a estrutura sincrônica do material da linguagem, na medida em que cada elemento adquire nela seu emprego exato por ser diferente dos outros; é esse o princípio de distribuição que rege sozinho a função dos elementos da língua em seus diferentes níveis, desde o par da oposição fonemática até as locuções compostas. A segunda rede, do significado, é o conjunto diacrônico dos discursos concretamente proferidos, que reage historicamente à primeira, assim como a estrutura desta determina os caminhos da segunda. Aqui, o que domina é a unidade de significação, que revela jamais resumir-se a uma indicação pura do real, mas sempre remeter a uma outra significação (LACAN, 1998, p. 415).

O processo de deslocamento de significantes é também o movimento do desejo - que depende de um espaço vazio, de falha, de falta-a-ser do sujeito, para manter-se circulante: "O desejo é a metonímia da falta-a-ser" (LACAN, 1998, p. 646). Este vazio estrutural leva Lacan a formalizar um conceito: o objeto a - objeto inapreensível e sem imagem. “Ele não é especularizável, ou seja, dele não se pode formar uma imagem (...); ele não é nomeável, ou seja, não pode ser reduzido a uma 
designação permanente e estável, que corresponderia, por exemplo, a uma espécie de fixação de sua significação" (DUNKER, 2006, p. 05). A este objeto, correspondem "figuras", com as quais Dunker trabalha homologias entre a arte e a psicanálise. Junto a Lacan, ele postula as "figuras do objeto a" que, na obra de arte, remetem a um lugar de não inscrição, a um impossível de se imaginarizar. Estas figuras são: o excesso que polui a obra (indicando a falta); o vazio; o informe, a deformação e a anamorfose, ou a tematização dos limites da forma e do quadro; e uma espécie de descrença no olhar, implicados no estranhamento e na despersonalização.

Trata-se de colocar em dúvida ou desacreditar do que se vê. Um sentimento de estranhamento e de despersonalização abala o juízo de existência. Não há nenhuma distorção da percepção, ela não é mais nítida nem menos intensa. Não há nenhuma obstrução da lembrança. Mesmo assim a experiência questiona o que vê, põe em dúvida o estatuto de realidade da imagem que se tem pela frente. A experiência estética poderia ser aproximada aqui de uma espécie de descrença no que se vê (DUNKER, 2006, p. 03)

Dunker destaca a anamorfose: conseguir enxergar uma forma apenas com certa posição do olhar (um jogo com a posição do olhar, com o que se pode ou não enxergar).

A anamorfose ou anamorfismo é uma deformação reversível de uma imagem produzida mediante procedimento óptico (utilizando, por exemplo, um espelho curvo), ou por meio de um procedimento matemático. É um efeito perspectivo utilizado na arte para forçar o observador a um determinado ponto de vista preestabelecido ou privilegiado, desde o qual o elemento toma uma forma proporcionada e clara (Hassan, 2007, p. 04).

O exemplo clássico é a obra "Os Embaixadores", de Holbein, cujo detalhe (uma caveira) só se pode ver a partir de determinado ângulo da visão.

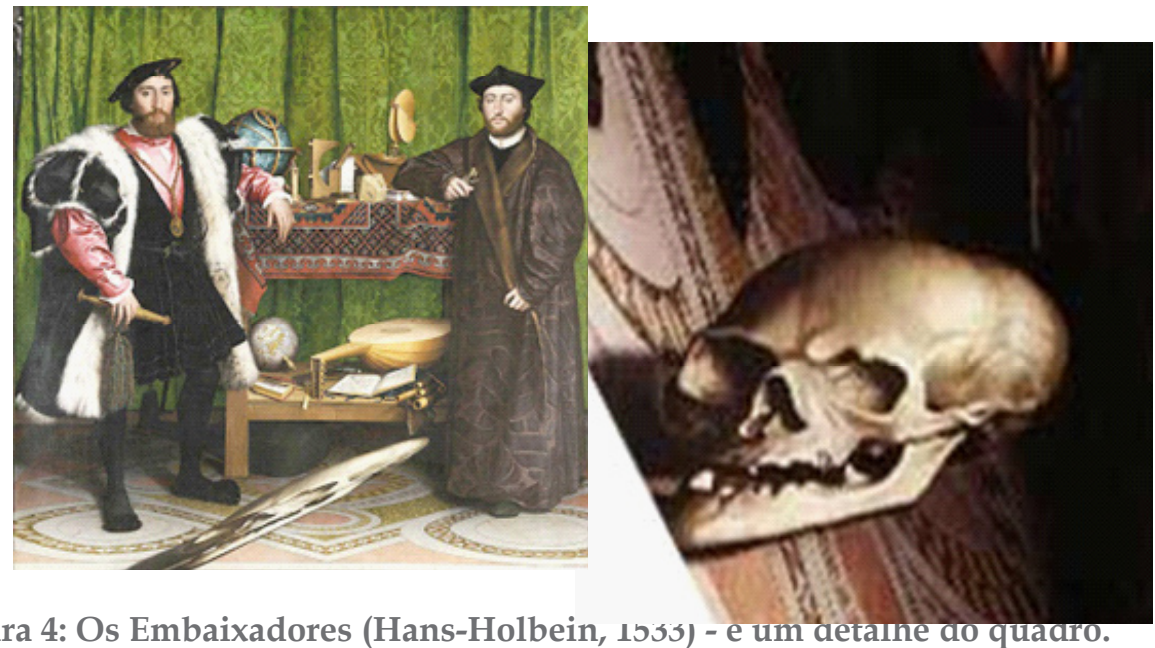

Figura 4: Os Embaixadores (Hans-Holbein, 15ss) - e um aetaine aro quararo.

Para Lacan, o quadro deve ser considerado como uma espécie de armadilha para o olhar. Para apreender a imagem, o sujeito deve colocar-se em uma dada distância da tela. Nesta posição ele reconstrói o caminho da perspectiva proposta pelo quadro, as imagens ganham forma, o espaço se organiza segundo uma geometria que permite incluir o ponto de vista do pintor (DUNKER, 2006, p. 04) 


\section{Cena 15}

\section{Rejane Kasting Arruda}

exemplo, quando acontece no escuro, fora dos limites da luz; ou quando propõe o deslocamento do olhar do espectador para "ver outra coisa"; quando este recorta o que vê em uma cena poluída; ou a sobreposição dos enquadramentos interroga e faz circular, deslizar; ou, ainda, com o efeito de vazio (de uma imensidão de água ou areia) que não lhe deixa ver outra coisa senão o mesmo. Ou, ainda, trazendo para a cena a visualidade da rua; do sacrifício; a poética do ritual; do grotesco, da crítica, da paródia; da ironia e da tribuna; dos bastidores; da deformação e do sem sentido. São tipos (modalidades) de um excesso. Não se reduzem à representação de um discurso, mas se abrem para uma produção girando em torno do que não se pega - tocando em forma de afeto. Muitas vezes, no pós-dramático, diferentes visualidades implicam fissuras, coisas soltas se abrindo no espaço de uma escuta onde o espectador produz o não saber (a evidência de um limite).

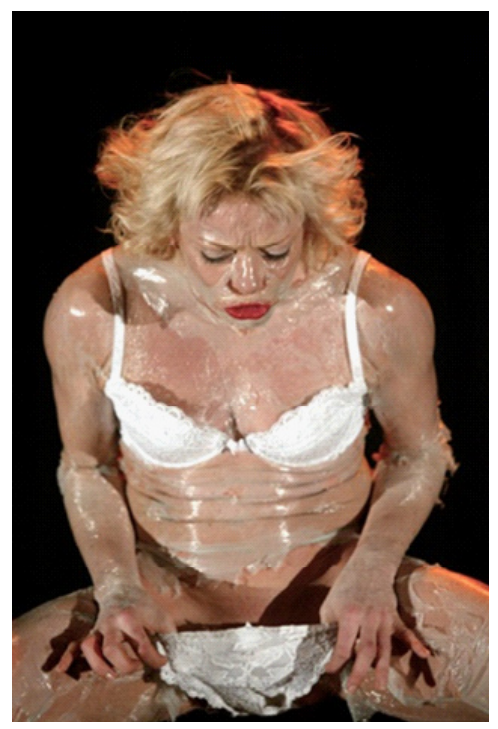

Figura 5: Elle était et elle est, même (Jan Fabre, 2004)

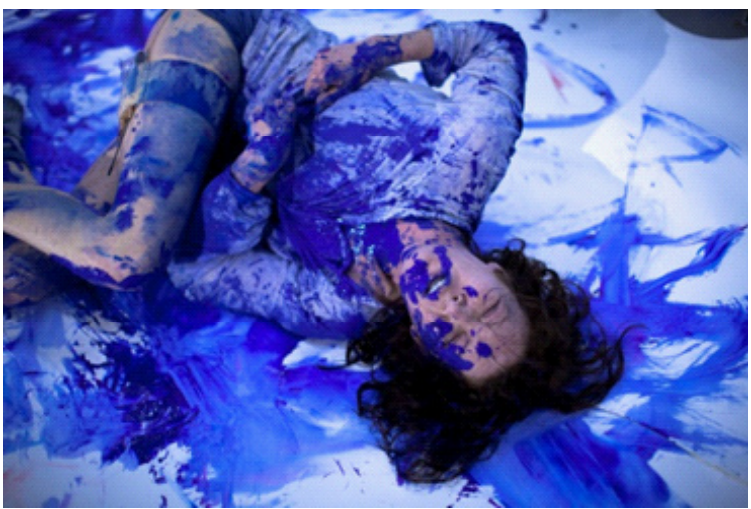

Figura 6: Cries and Whispers (Ivo Van Hove's, 2011) 


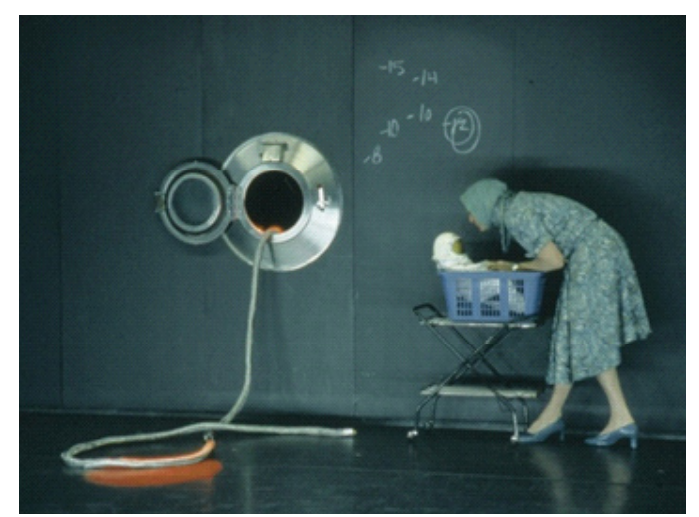

Figura 7: Far Side of the Moon (Lepage, 2012)

Um dos princípios que aparecem no pós-dramático é não justificar ou atribuir uma sobreposição de sentido às ações, mas operar por montagem - onde materiais são justapostos sem que impliquem uma totalidade. A inscrição (de um modo singular) da visualidade de um objeto, por exemplo, é avessa à necessidade de circunscrevê-la em um discurso que caiba dentro dos limites do imaginário (das relações imaginárias, de identificação) do eu. O esforço do sentido apaga o efeito estético. A sobredeterminação do sentido, através da palavra ou da imagem que se quer inteira, gera uma espécie de queda da visualidade.

Em “ A Imagem entre o Olho e o Olhar" Dunker expõe uma passagem do texto de Freud "Sobre o mecanismo psíquico da desmemória" (1898), onde o psicanalista relata a tentativa de lembrar o nome de um pintor de afrescos: Luca Signorelli: “(...) com particular nitidez tinha ante meus olhos o auto-retrato do pintor - o rosto severo, as mãos entrelaçadas" (FREUD, 1988, p. 282 apud DUNKER, 2006, p. 3). Quando consegue, por fim, lembrar-se do nome Signorelli, "a recordação hipernítida dos traços faciais empalideceu de imediato" (idem). A imagem, antes intensa e carregada, torna-se pálida e rarefeita na medida em que o nome do pintor se completa (e com ele o sentido do esquecimento) ${ }^{4}:$ "A obstrução do sentido seria correlativa à intensificação da visualidade e, inversamente, a retomada do sentido, pela interpretação do esquecimento, corresponderia ao decaimento da visualidade" (DUNKER, 2006, p. 2).

Pensando na oposição entre sentido e efeito estético, no que diz respeito à ação de uma peça dramática, esta deve ser tomada como uma modalidade de enquadramento: como visualidade (da ação) e não o seu sentido. Ao se criar o enquadramento ficcional, uma lógica do sentido pode ser tomada como campo de extração de materiais isoláveis e passíveis de arranjo, mas não restringirá as escolhas. O que restringe as escolhas é a inscrição em uma poética da cena. Os limites da forma podem ser tematizados com as deformações e alterações das bordas corporais, o reenquadramento dos objetos e as projeções. Mas também com os próprios limites da ficção que se evoca e rompe. Pode-se dizer que a cena trabalha a descrença no olhar quando se aproxima de um efeito de alucinação que Roubine postula para o "como se" (tivesse acontecendo) ou "como se fosse verdade": a desconfiança do que se vê quando se propõe a imagem alucinatória de uma ficção como se fosse verdade. Testemunha-se a figura do excesso na multiplicação de objetos, alterações do tempo, exacerbação do afeto; defasagem entre enquadramentos justapostos; ou uma repentina descoberta do olhar capturando algo: a produção de um efeito de anamorfose quando o espectador se flagra com outra posição do olhar sobre o drama. $\mathrm{O}$ fato de diluir-se a forma do enredo pode ser um viés da $4 \quad$ A memória advém da cadeia associativa. Freud lembra-se de Botticelli e Boltrattio (outros dois pintores). Em seguida, a repetição da sílaba "bo" o leva à Bósnia Herrzegovina, que o leva a Herr: maneira pela qual os médicos se referem aos pacientes para comunicar a morte: "A reconstrução se completa pela lembrança de que na cidade de Trafoi - nome próprio contido em Boltrattio - Freud recebera a notícia do suicídio de uma paciente acometido por uma perturbação incurável" (DUNKER, 2006, p. 02). 
questão dos limites da forma. A encenação ofusca as relações intersubjetivas a serem representadas e inscritas neste enredo. Há uma oposição entre visualidades que empalidecem ou evocam outras. Esta é uma busca cuja estratégia é: diálogo, extração de materiais, arranjo, corte.

\section{Fazer ver outra coisa}

O teatro é uma arte e ao mesmo tempo talvez mais que uma arte

(V. Meyerhold)

Um dos motes que norteou a construção plástico-corporal exacerbada durante o século XX foi uma libertação dos valores burgueses, seus mecanismos de determinação e institucionalização. Vemos, em projetos de Meyehold, Artaud, surrealistas, dadaístas ou Bauhaus, de Brecht e Teatro do Absurdo, uma espécie de fazer ver o que não está sendo visto; para além de um olhar institucionalizado, habituado, comum. Uma espécie de "quebra do olhar". Também no naturalismo de Antoine o objetivo era fazer ver o que não estava sendo visto em um teatro escravizado pelas idealizações românticas e pelos dramalhões melodramáticos. Antoine criou um retrato da prostituição sem a idealização romântica de "Dama das Camélias", provocando repulsa. Foi difícil para o público ver a crueza e deparar-se com "o desgosto que causavam as cenas desagradáveis de uma mulher que apodrecia consumida pela varíola" (BUSNACH, 1884, p. 205 apud FARIA, 1998, p. 39). A "Dama das Camélias" (1851) foi o primeiro grande sucesso da escola realista. Mas, segundo Carlson, apesar de contribuir para "uma sugestão do realisto fatia-de-vida", Alexandre Dumas Filho se diferencia dos naturalistas e realistas subsequentes graças à dedicação à moral do drama. Zola tomava-o por idealista: "enquanto Dumas queria corrigir o homem, Zola queria examiná-lo" (CARLSON, 1997, p. 267-269).

Após a Primeira Grande Guerra as grandes narrativas (o discurso sobre o mundo) desabam. Inicia-se a trajetória, que vemos em movimento retroativo, centrada nas oposições paradigmáticas (à atuação dramática e à atuação naturalista) das quais deve se valer a extração de materiais para um teatro contemporâneo. Podemos dizer que, no projeto de inscrever o efeito de cotidianidade em cena (presente no naturalismo e que muitas vezes se confunde com ele) estão postos: vertigem, delírio e uma espécie de "não acredito no que vejo": "descrença no olhar". A cotidianidade do corpo (quando se investe em outra poética que não é a da deformação e abstração das formas corporais) também estranha.

Já um arranjo de Meyerhold tem outros materiais para estranhar; uma espécie de choque que se contrapõe ao universo burguês evocado pela palavra. Um exemplo é a sua montagem de "Casa de Bonecas" de Ibsen, em 1922, designada com o subtítulo "A História de Nora Helmer ou Como uma mulher preferiu a independência e o trabalho ao veneno da família burguesa". Graças ao entulho que compõe o cenário, a frase "Me sinto confortável na minha sala diante da lareira", de Helmer, resulta irônica (Abensour, 2011). Na montagem de "As Auroras", em 1920, quando um dos personagens vai proferir o hino de vitória, Meyehold introduz a notícia esperada pelo povo: o Exército Vermelho se apoderou de Perekop e colocou fim à guerra civil - causando comoção na plateia. Neste mesmo espetáculo os atores se dirigem ao espectador convocando a sua opinião. São materiais que se pode misturar não somente a partir de uma extração direta dos diferentes arranjos meyerholdianos, mas na medida em que estão hoje na cultura inscritos. Mas talvez o principal campo de extração meyerholdiano seja o grotesco, que ele propunha a partir de estudos dos caprichos (desenhos) de Goya, Daumier e Callot - figuras que não apenas "incitam a imaginação" (como dizia), mas se 
encarnam no ator: criação estranhada (em oposição ao realismo) quando este se assemelha ao bufão.

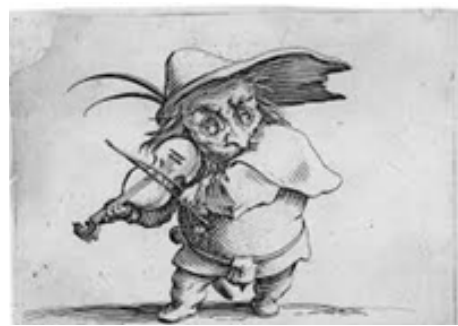

Callot

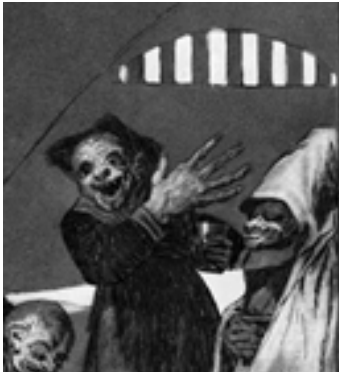

Goya

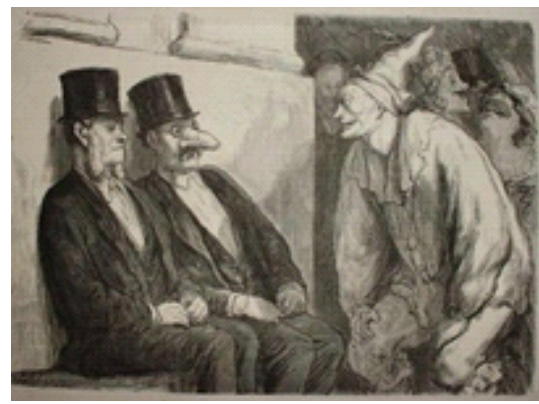

Daumier

Figura 8: Material proposto por Meyerhold aos atores

Testemunha-se a função de um enquadramento também através da música: "no sentido da restrição, pois a música intervém no tempo e o isolamento numa pequena plataforma restringe o espaço" (ASLAN, 1994, p. 152) - e outros materiais. Segundo Aslan, Meyerhold "restringe a ação com pausas entre as falas, posturas estáticas ou intrusão de pantomimas; subverte o encadeamento, impõe entonações insólitas, com a voz fabricada" (idem). Kirby associa o ator meyerholdiano a uma marionete animada. Percebe-se uma oposição ao corpo mimético realista, onde as noções de naturalidade e cotidianidade estão implicadas. Em "Inspetor Geral" (1926), ele substitui personagens por manequins; utiliza telas alternando a atuação filmada e ao vivo; coloca passagens de outros textos no espetáculo ("Os Jogadores”, “As Almas Mortas” e "As Histórias de S. Petersburgo”, também de Gogol); acrescenta personagens mudas; constrói um coro que não havia; cria figuras episódicas; transforma monólogos em diálogos; coloca o mesmo ator interpretando vários personagens para frustrar as possibilidades de identificação (Abensour, 2011).

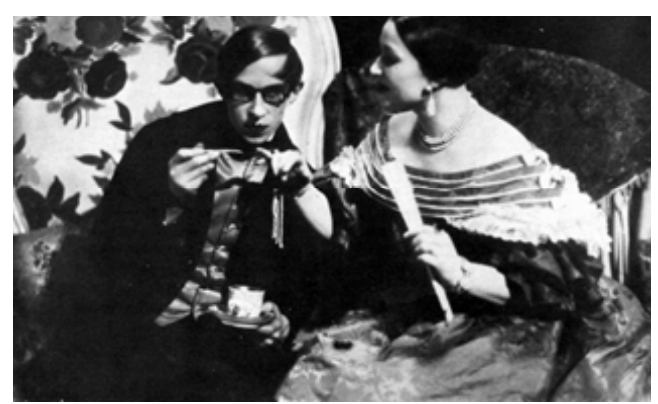

Figura 9: O Inspetor Geral (Meyerhold, 1926) 


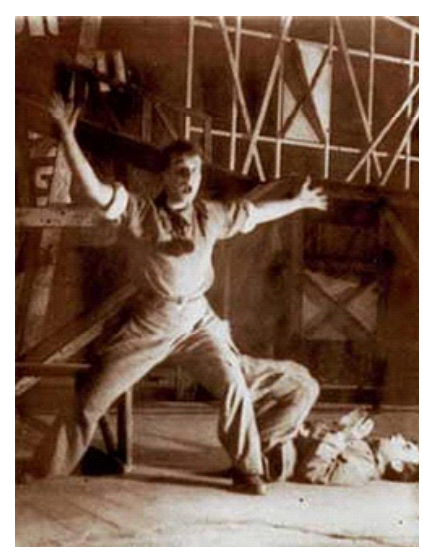

Figura 10: O Corno Magnífico (Meyerhold, 1922)

Outro arranjo paradigmático, podemos encontrar em Artaud. Ao mesmo tempo em que designa a submissão ao texto como "barco fúnebre", critica a visualidade estéril da mise-en-scene; postula um teatro independente da literatura, apesar de tomar grandes textos como referência de algo que se deve evocar para além da mimese da realidade. O teatro deve possibilitar a "exploração de infinitos deslocamentos interiores" e para isto é necessário se libertar da representação e encontrar a vida: "Reatralizar o teatro e relançá-lo na vida" (ARTAUD, 2008, p. 26). É o objetivo de Artaud e, se opondo ao naturalismo com suas tendências humanistas, encantou-se pelo teatro balinês graças a sua "impessoalidade":

Tudo nos atores é impessoal - talvez por se diferenciar radicalmente do naturalismo e sua construção pessoal. Os gestos respondem a uma espécie de matemática (...) nessa despersonalização sistemática, nessas expressões puramente musculares que são como máscaras sobre o rosto, tudo tem o seu significado, tudo produz o máximo efeito (ARTAUD apud MIRALLES, 1979, p. 45-46)

A vida não está presente na representação do indivíduo em cena (mas em algo que se dá como excesso). $\mathrm{O}$ encenador deve "fixar as imagens que nascerão em nós nuas, excessivas e ir até o extremo destas imagens" (ARTAUD, 2008, p. 27). Assim, ele propunha um teatro "raro", que se pode encontrar no circo, mas que, no entanto, diz do espírito (e se estabelece como metafísica). O espectador não deveria "ir lá para ver, mas para participar" (idem), experimentando "a angústia metafísica que as cenas representadas provocarão" (ARTAUD apud MIRALLES, 1979, p. 41) ou “a insônia febril, o passo dos corredores, o salto mortal e a potência de uma bofetada" (GLUSBERG, 2007, p. 12) - já presentes no futurismo de Marinetti. O teatro como "praga libertadora que desencadeia poderes e possibilidades sombrias” (CARLSON, 1997, p. 381).

A peça radiofônica "Para Acabar de Vez com o Juízo de Deus" (Artaud, 1948) testemunha uma pesquisa com a sonoridade: ganidos, gritos, ruídos, alterações radicais de altura e volume - além de uma visualidade do transe e do ritual; espécie de possessão - vestígios do expressionismo:

O isolamento e ampliação do traço em detrimento do todo; o uso da voz para agir sobre o espectador; descargas sonoras e visuais; a palavra ritmicamente articulada; diálogos sem ordem; a presença da poesia e prosa; gestos isolados e estilizados; o corpo flexível e desarticulado do ator; o trabalho com as zonas de tensão, as mãos 
crispadas, os gestos cortando o espaço; a ideia de coreografia, com batidas de pés, tremores, crispações, projeções da cabeça e dos braços para trás ${ }^{5}$ (SALLES, s.d.)

Tal como em “O Dibuk" (Vankhtangov, 1922), há no corpo uma desconstrução do humano:

Gritos guturais, guinchos, salmodiar doloroso, musicalidade e uma interpretação gestual com balanço de cabeça e pernas, torso lançado para trás e/ou com as costas arqueadas, gestos largos e intensificados. Havia uma dança dos mendigos que chamou a atenção por sua força encantatória, um balé grotesco, macabro, com braços que se agitavam como morcego (idem).

Desconstrução do humano que podemos encontrar, também, na palavra; vazão ao jogo do som vazio; hiato vertiginoso quando não se evoca mais um sentido: “Kré É preciso que tudo puc te Kre esteja arrumado puk te pek por um fio li le kre numa ordem pek ti le e fulminante kruk pte" 6

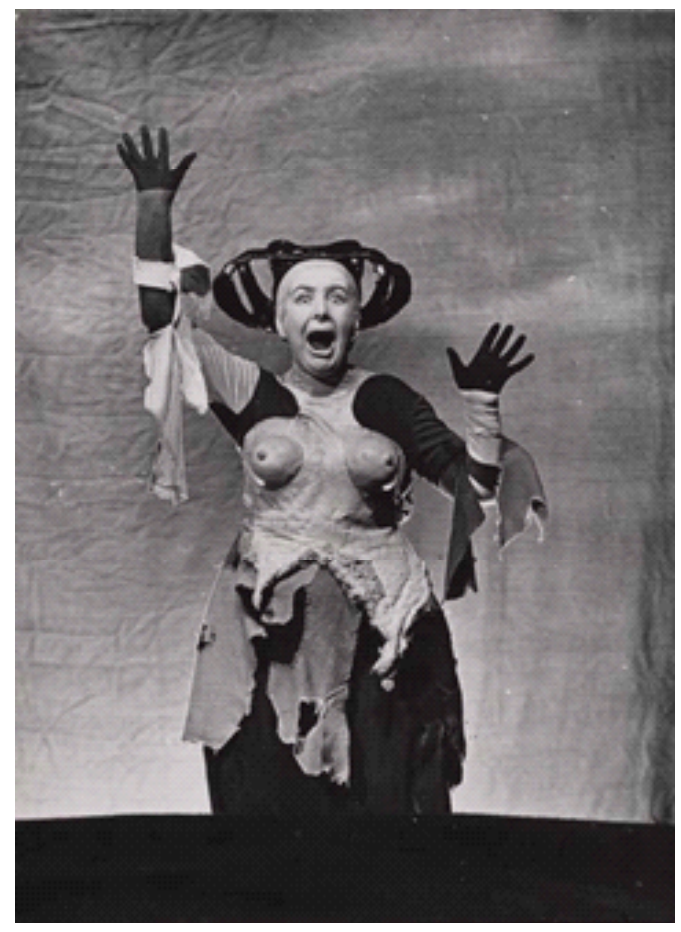

Figura 11: Montagem de “O Rinoceronte" (Ionesco) dirigida por Tadeusz Kantor (1961)

O absurdo da linguagem encontra lugar no "novo estilo de drama antirrealista na França que haveria de tornar-se o teatro de vanguarda mais bem-sucedido que o século já produzira" (CARLSON, 1997, p. 399). As dramaturgias de Ionesco, Beckett e Adamov foram designadas "Teatro do Absurdo" por Martin Esslin a partir da "literatura do absurdo" que, inspirada no "Mito de Sísifo" (1951) de Camus, tematizava o eterno (e absurdo) recomeçar humano (apesar destes dramaturgos preferirem "Teatro da Erosão" ou "Teatro Abstrato").

Puro drama. Antitemático, antiideológico, anti-social-realista, antifilosófico, antipsicologia de boulevard, antiburguês - a redescoberta de um teatro livre" - contra

5 SALLES, Nara. Teatro Expressionista. Portal São Francisco: História do Teatro. Disponível em: http://www. portalsaofrancisco.com.br/alfa/historia-do-teatro/teatro-expressionista-3.php Acesso em 16/01/2014.

6 Trecho de "Para Acabar de Vez com o Juízo de Deus". Fonte: KIFFER, Ana. Artaud, Momo ou Monstro? Centro de Estudos Claudio Ulpiano, 2010. Disponível em: http://claudioulpiano.org.br.s87743.gridserver.com/?p=258 (Acesso em 06/01/2014) 
“as convenções aceitas do teatro francês tradicional, a ênfase na palavra, o vínculo de causa e efeito, a tendência ao realismo e o desenvolvimento psicológico do caráter (IONESCO, 1964, p. 216-217 apud CARLSON, 1997, p. 400).

A visualidade do nonsense aparece, junto a traços do Music Hall e Vaudeville. A influência se estende a Buster Keaton, Charles Chaplin, Irmãos Marx, Joyce e Kafka. Propriamente um híbrido, cuja produção de estilo é marcante. Outros dramaturgos são nomeados "absurdos": Arrabal, Jean Genet, Harold Pinter, Tom Stoppard, Friedhich Dürrenmatt, Edward Albee, Jean Tardieu. O marco inicial desta produção se deve a Beckett ("Esperando Godot", 1949) e Ionesco ("A Cantora Careca" e "A Lição", ambos de 1950). Ionesco afirmou que "As Cadeiras" era uma tentativa de "alargar as fronteiras atuais do drama". Um debate com o campo dramatúrgico então institucionalizado, para instalar outra lógica na construção dramática - propondo uma espécie de abstração que:

(...) purifica a ação dramática do que lhe é intrínseco: enredo, características acidentais dos personagens, seus nomes, posição social e contexto histórico, razões aparentes do conflito dramático e todas as justificativas, explicações e lógica do próprio conflito para obter um conflito abstrato sem motivação psicológica (idem).

Uma questão que se abre é a construção do estilo de atuação para as peças do Absurdo - com a estilização do gesto, absorvendo a influência dos mímicos (Jean-Pierre Barrault foi o primeiro a dirigir "O Rinoceronte"). Outra questão é o divórcio entre a palavra e o mundo. A palavra esvaziase; é a linguagem que é absurda. "A Cantora Careca" foi criada a partir de um manual de inglês, com frases do tipo: "Eu não tenho o chapéu do meu vizinho, mas tenho a bengala da minha tia". A gratuidade é visível - o que a torna cômica. Segundo Ávila, Ionesco “denuncia o absurdo de certa linguagem cotidiana, em que as palavras, demasiado carregadas de significações as mais diversas, perderam o seu valor e passaram a não significar coisa nenhuma" . Além do desgaste da linguagem, a visualidade das personagens se quebra. Elas se decompõem no suporte de uma voz: uma fala vazia.

Ai! As verdades elementares e sábias que eles trocavam, encadeadas umas às outras, tinham se tornado insanas, a linguagem se desarticulara, os personagens se descompuseram; a fala, absurda, se esvaziara de seu conteúdo e tudo terminava por uma briga cujos motivos eram impossíveis de saber, já que meus heróis disparavam não réplicas, nem mesmo pedaços de frases, nem palavras, mas sílabas, consoantes, vogais!... Para mim, tratava-se de um tipo de desmoronamento do real. As palavras tinham se tornado revestimentos sonoros desprovidos de sentido; os personagens também, é claro, esvaziaram-se de sua psicologia e o mundo me aparecia numa luz insólita, talvez em sua verdadeira luz, além das interpretações e de uma causalidade arbitrária (IONESCO, 2006, p. 247-248 apud OLIVEIRA, 2009, p. 05)

Aqui a cotidianidade é avessa à construção do drama. Os personagens:

(...) não sabem mais ser, eles podem "se tornar" qualquer um, qualquer coisa, uma vez que não sendo, eles são apenas os outros, o mundo do impessoal, eles são intercambiáveis: pode-se colocar Martin no lugar de Smith e vice-versa, não se notará (idem).

Em "As Cadeiras" um casal de velhos vive numa torre no centro de uma ilha. Preparam uma 
grande recepção para a qual convidam personalidades. Passam o tempo enfileirando cadeiras para convidados que não virão. Deparamo-nos com o vazio como fundamento da experiência estética. Ionesco afirma: "é a expressão de uma angústia e de uma interrogação para a qual eu próprio aguardo uma resposta"7 "Rinoceronte", no entanto, está atrelado a um sentido: o sentido de uma crítica ao nazismo e a aversão a qualquer tipo de histeria coletiva. As pessoas viram rinoceronte e, tal como nos regimes totalitários, são contagiados e massificados. Resta Bérenger, simbolizando a resistência da condição humana: "A mim é que vocês não pegam! Eu não vos seguirei! Eu não vos compreendo! Continuarei como sou. Sou humano, um ser humano!"

Também as peças de Beckett, como "Esperando Godot" (que estreou em Paris em 1952 sob a direção de Roger Blin) e "Fim de Jogo" (que estreia em 1957 no "Royal Court Theatre"), marcaram pela visualidade do vazio. O velho e cego Hamm com seu serviçal Clov (cujo encadeamento foge a qualquer justificativa, se impondo como puro efeito de grafia). Embora a relação entre os dois se estabeleça, já não se sabe se, há três minutos, Clov fez, exatamente, o que está novamente a fazer. Há críticos que pontuam a influência de James Joyce na obra de Beckett. Segundo Badiou "a obra de Beckett se abre para o acaso, para os incidentes e, portanto, para a ideia de sorte" - tal como a de Joyce. “Em ‘O Inominável' (romance de 1949) lemos: 'ninguém me obriga, não há ninguém, é um acidente, é um fato'" (BADIOU, 2003 apud AMARANTE, 2009, p. 01). Segundo Amarante:

Beckett e Joyce compartilham uma mesma desconfiança para com a linguagem, como se verá à frente. Sendo que essa linguagem, da qual se origina uma fala incessante, tende a gerar, na obra de ambos, personagens obscurecidos pela voz, ou seja, personagens sem corpo (...). Esses personagens, feitos de linguagem, acentuam e traduzem a atmosfera de sonho, de devaneio de suas obras (AMARANTE, 2009, p. $02)$.

Poderíamos completar: "atmosfera de errância e incerteza". "Estou no quarto de minha mãe. Sou eu que moro lá agora. Não sei como cheguei lá. Numa ambulância talvez" (idem). Descorporificação: “VLADIMIR: Veja só! Você, aqui, de volta. / ESTRAGON: Estou?”. Segundo Badiou: "Tudo se reduz à voz. Plantado num jarro ou cravado numa cama de hospital, o corpo, cativo, mutilado, agonizante, é apenas o suporte quase perdido de uma fala" (BADIOU, 2003 apud AMARANTE, 2009, p. 05).

Sou de palavras, sou feito de palavras, das palavras dos outros, que outros, e o lugar também, o ar também, as paredes, o chão, o teto, palavras, o universo está todo aqui, comigo, sou o ar, as paredes, o emparedado, tudo cede, tudo se abre, anda a deriva (...) (idem)

A determinação de uma voz enquanto o corpo se dilui é radicalizada na peça de 1973 "Não Eu": apenas uma boca iluminada em cena. Há fala compulsiva. No entanto, não "do Eu". A visualidade do Eu se perde. Aqui se chega à concretização de um projeto - e talvez Carlson tenha razão em afirmar que o Teatro do Absurdo é o mais bem sucedido movimento de vanguarda do século XX. Se a história do teatro no século XX se organiza em torno da recusa de um realismo; da visualidade de uma diegese fechada onde indivíduos se encontram implicados em relações intersubjetivas a serem representadas; aqui não há indivíduo; não há "eu" corporificado. O fato de

$7 \quad$ AVILA, Norberto. Sobre o Teatro de Ionesco. Paris, s/d, p. 01. Disponível em: http://www.yumpu.com/pt/ document/view/13037077/n-quando-nicolas-bataille-apresentava-a-uma-plateia-quase-a- Acesso em 08/01/2014. 
não haver um corpo inteiro é representativo. No entanto, nos diversos movimentos, que primaram por linhas corporais (como a Bauhaus), apesar de o corpo estar presente, extrapola-se a visualidade do Eu - o que nos faz concluir que, em cena, o indivíduo é uma construção, evocação (na qual se pode investir ou não). No caso do drama é nisto que se investe - e na progressão da relação e conflito com o mundo. No caso da poética estranhada é isto que se desmancha.

Ao mesmo tempo, Roubine abre a perspectiva de um reconhecimento do que pode estranhar também na atuação naturalista na medida em que causa a vertigem do olhar - estabelecendo esta, também, como um campo paradigmático para a extração de materiais, que poderão constituir, junto com outros, um jogo de enquadramento (de uma obra que ainda está por vir).

\section{Referências Bibliográficas:}

ABENSOUR, Gérard. Vsevold Meierhold ou A Invenção da Encenação. São Paulo: Perspectiva, 2011.

AMARANTE, Dirce. Joyce e Beckett, Pés Diferentes no Mesmo Sapato. Revista Sibila: Poesia e Crítica Literária, 2009. Disponível em: http://sibila.com.br/critica/joyce-e-beckettpes-diferentes-nummesmo-sapato/3019. Acesso em: 23/6/2014.

ARTAUD, Antonin. Linguagem e Vida. São Paulo: Perspectiva, 2008.

ASLAN, Odette. O Ator no Século XX. São Paulo: Perspectiva, 1994.

BRAGA, Bya. Ator de Prova: Questões para uma Ação-física coral. Belo Horizonte, IV Reunião Científica de Pesquisa e Pós-graduação em Artes Cênicas, 2007.

CARLSON, Marvin. Teorias do Teatro. São Paulo: Unesp,1997.

DUNKER, Christian. A Imagem entre o Olho e o Olhar In: Sobre Arte e Psicanálise. São Paulo: Escuta, 2006, v.1, p. 14-29.

FREUD, S. Carta a Romain Rolland (uma perturbação de recordação na Acrópole) (1936). In: Sigmund Freud Obras Completas XXII, Buenos Aires: Amorrortu, 1988.

GLUSBERG, Jorge. A Arte da Performance. São Paulo: Perspectiva, 2007.

LACAN, Jacques. Escritos. Rio de Janeiro: Jorge Zahar Ed., 1998.

MIRALLES, Alberto. Novos rumos de teatro. Rio de Janeiro: Salvat Editora, 1979.

OLIVEIRA, Patrícia. Engène Ionesco ridicularizando a própria linguagem: uma leitura de A Cantora Careca. VI Seminário de Iniciação Científica, Só Letras, 2009. Disponível em: https:/ / www.yumpu. com/pt/document/view/13037243/uma-leitura-de-a-cantoracareca-uenp Acesso em 23/6/2014.

ROUBINE, Jean-Jacques. Introdução às grandes teorias do teatro. Rio de Janeiro: Jorge Zahar, 2003.

\section{Referências Fotográficas:}

Figura 1: Téâtre Libre, fundado em 1887. Montagem de "A Terra" de Zola, por Antoine, em 1902. Théâtre Français History. Disponível em: http://www.artsalive.ca/en/thf/histoire/ 
metteursenscene.html Acesso em: 23/6/2014.

Figura 2: Imagens de Espetáculos de Romeo Castellucci. Espetáculo Giulio Cesare, 1997. Disponível em: http://www.2013.malta-festival.pl/en/program/forum-romeo-castellucci-juliusz-cezar-1997/ gallery Espetáculo Giulio Cesare, 1997. Disponível em: http://www.milanoltre.org/popscheda. asp?id=205 Espetáculo Genesi, 1999. Disponível em: http:/ / www.cultureteatrali.org/focus-on/607conversando-con-romeo-castellucci.html Espetáculo Orestea, 1995. Disponível em: http:/ /www. equilibriarte.net/art/48159\&detail. Acesso em: 23/6/2014.

Figura 3: Night Train (Katie Mitchell, 2013). Fotografia de Stephen Cummiskey. Disponível em: http:/ / www.exberliner.com/blogs/the-theatertreffen-blog/regietheater-auf-englisch/ Acesso em: $23 / 6 / 2014$.

Figura 4: Hans Holbein, O Jovem (c.1497-1543) - "Os embaixadores", 1533, óleo e têmpera sobre painel de carvalho 2,07 x 2,09. National Gallery, Londres, Reino Unido. Disponível em: http:/ / umaobra.tumblr.com/post/77851755964/hans-holbein-o-jovem-c-1497-1543-os Acesso em: 23/6/2014.

Figura 5: Elle était et elle est, meme (Jan Fabre, 2004). Fotografia de W. Bergmann. Disponível em: http://www.dbnl.org/tekst/_sep001200501_01/_sep001200501_01_0029.php Acesso em: 23/8/2014.

Figura 6: Cries and Whispers (Ivo Van Hove's, 2011). Disponível em: http:/ /www.zubb.nl/ theater/843/toneelgroep-amsterdam-kreten-en-gefluister Acesso em: 23/6/2014.

Figura 7: Far Side of the Moon (Lepage, 2012)

Figura 8: Material proposto por Meyerhold aos atores. Jacques Callot (1592-1635): Les Gobbi - Le jouer de violon. Disponível em: http:// fr.wikipedia.org/wiki/Jacques_Callot. Goya (1746-1828): Capricho ${ }^{\circ} 49$ - Duendecitos. Disponível em http:/ /fr.wikipedia.org/wiki/Los_Caprichos. Daumier: Scène du Carnaval de Paris (1868). Disponível em: http://fr.wikipedia.org/wiki/ Carnaval_de_Paris. Acesso em: 23/6/2014.

Figura 9: O Inspetor Geral (Meyerhold, 1926).

Figura 10: O Corno Magnífico (Meyerhold, 1922). Disponível em: http://www.glopad.org/pi/en/ record/production/567. Acesso em: 23/6/2014.

Figura 11: Montagem de "O Rinoceronte" (Ionesco) dirigida por Tadeusz Kantor (1961). Disponível em: http:/ / fluctuat.premiere.fr/Diaporamas/Eugene-Ionesco-prince-de-1-Absurde-3156720 Acesso em: 23/6/2014. 